\title{
Úton az egészségorientált sportklubmodell bevezetéséhez Magyarországon
}

\author{
On the way towards health-oriented sport clubs in Hungary
}

\author{
Szerzők: $\quad$ Köteles Gábor ${ }^{\mathrm{a}} \triangle$, Veress Réka ${ }^{\mathrm{b}}$ \\ a: Nemzeti Diák-Hallgatói és Szabadidősport Szövetség, b: Emberi Erőforrások Minisztériuma
}

Beküldve: 2019. 01. 22.

doi: $\quad$ 10.24365/ef.v60i2.405

\begin{abstract}
Összefoglaló: „Több, mint egy klub” néven az egészségközpontú sportegyesületek modelljén nyugvó, társadalmi innovációs, kísérleti projektet indított a Nemzeti Diák-, Hallgatói és Szabadidősport Szövetség (NDHSZ) és a Debreceni Egyetemi Atlétikai Club (DEAC). A 'Több, mint egy klub' projekt célja az egészségfejlesztő testmozgás szemléletére épülő, innovatív modell kidolgozása és terjesztése. A nyitottságra építő modellt alkalmazó sportegyesületek szervezett keretek között zajló, egészségtudatos testedzési lehetőséget kínálnak a helyi lakosság széles rétegeinek, miközben lehetőségük nyílik a szervezeti megújulásra is. A projekt szemlélete az ún. Sports Clubs for Health ( $\mathrm{SCforH)}$ ) az egészségorientált sportklubok modelljén alapszik, amelynek megvalósítását az Európai Unió 2013-ban ajánlásként fogalmazta meg a tagállamok számára. A cikkben a projektet megalapozó SCforH szemléletet mutatjuk be.

Kulcsszavak: sportklub; egészség; sportegyesület; mozgás; innováció
\end{abstract}

Summary: The National School, University and Leisure Sport Federation in cooperation with the University of Debrecen's Athletic Club launched a social innovation project based on the Sports Clubs for Health (SCforH) approach. The title of the pilot project is "More than a club". In the framework of the project, the partners aim to widen and develop the sport services of the clubs, highlighting the health-benefits of the sports; using their local and regional capacities, so that wider groups of the population will have access and benefit from the healthenhancing physical activities (HEPA). This will result regular HEPA opportunities provided by the club with the supervision of professional sport staff. The Sport Clubs for Health approach has been endorsed by the European Union and recommended to be implemented by the Member States in 2013. In this article the SCforH approach is presented.

Keywords: sports club; health; sport association; physical activit; innovation

\section{ÁLTALÁNOS BEVEZETŐ}

A Nemzeti Diák-, Hallgatói és Szabadidősport Szövetség (NDHSZ) és konzorciumi partnere, a Debreceni Egyetemi Atlétikai Club (DEAC) vissza nem térítendő támogatás nyert az egészségorientált sportklubmodell magyarországi fejlesztésére és tesztelésére.
A „Több, mint egy klub” EFOP - 5.2.1-17-201700007 kódszámú projekt keretében zajló fejlesztés annak a hiányosságnak a megoldására törekszik, hogy a hazai sportegyesületek portfóliójában az utánpótlás- és versenysport- megközelítés mellett az egészségvédő testmozgás (HEPA - healthenhancing physical activity) szélesebb tömegeket elérő koncepciója is szervezetten és tudatosan jelenjen meg. 
A „Sportegyesületek az egészségért” - megközelítésre épülő társadalmi innovációs kísérleti projekt keretében olyan komplex szolgáltatásfejlesztés megvalósítása a cél, amely a helyi, térségi sportegyesületek kapacitásaira épül. A sportegyesületek szolgáltatási csomagjaik átalakításával akár azok bővítésével - és az egészségmegőrző szemlélet alkalmazásával a lakosság szélesebb rétegének biztosítsanak képzett, szakemberek által felügyelt rendszeres testmozgási, sportolási lehetőséget. A modell célja, hogy a sportegyesületeket és országos sportszervezeteket arra ösztönözze, hogy minél több figyelmet fordítsanak az általuk kínált mozgásformák, sportágak egészségvédő potenciáljának kihasználására. A konzorciumban benyújtott pályázat feladata az, hogy próbálja ki és készítse elő az egészségorientált sportklubmodell magyarországi adaptációját, ezáltal járuljon hozzá a lakosság egészségfejlesztéséhez.

\section{A PILOT PROJEKT BEMUTATÁSA, AZ INNOVATÍV SZOLGÁLTATÁS (ÚJ MÓDSZER, ELÁRÁS) ÉS ÚJÍTÓ MÓDSZEREK ISMERTETÉSE}

A sportegyesületek alapfeladata a sporttevékenységek szervezése egy vagy több meghatározott sportágban. Ezekben az egyesületi tevékenységekben általában nagy hangsúlyt kapnak a versenysportok, a sportolói fejlődés és a sportteljesítmény, kisebb figyelem jut viszont a szabadidősportra és a fizikai aktivitás sport révén való növelésére. A fizikai aktivitás és a sportokban részvétel egészségre gyakorolt sokoldalú előnyeit bizonyítékok széles köre támasztja alá.

Az egészségvédelem általában nem szerepel a sportegyesületi szinten zajló fő tevékenységek között. A jó egészségi állapot azonban vitathatatlanul hasznos minden sportegyesületi tag számára, akik között tudásszint alapján amatőrök és élsportolók, életkor szerint pedig gyermekek és idősek is lehetnek. Milliós tagságuknak köszönhetően a sportegyesületek jelentik azt a legfontosabb helyszínt, ahol lehetőség nyílik az egészségjavító fizikai aktivitás és általában véve a sportolással elért egészség népszerúsítésére. Ezért született meg a "Sportegyesületek az egészségért" (a továbbiakban: SCforH) szemlélet, hogy segítse a sportegyesületekben rejlő hatalmas népegészségügyi potenciál kiaknázását.

Az SCforH-megközelítés gondolata 2007-ben Finnországban fogalmazódott meg, magát az SCforH-szemléletet hivatalosan 2009-ben' indították el, ekkor jelentek meg az első vonatkozó iránymutatások is, amelyeket azután 2011-ben' aktualizáltak. Az SCforH- projekt szellemiségét az Európai Bizottság olyannyira elismerte, hogy 2013-ban az EU tagállamainak ajánlásként fogalmazta meg az SCforH elveinek követését. Azóta az európai kutatói, szakpolitikai és sportközösségek tagjai határozottan érdeklődtek a „Sportegyesületek az egészségért" - koncepció iránt.

Az SCforH-szemlélet széles körű átvétele növelheti a sportokban való részvételt, egyúttal segítheti a sportegyesületi tagok egészségi állapotának javítását. Ez várhatóan a sportok jelentőségének nagyobb mértékû elismertségét és a sport társadalmi és közegészségügyi hatásainak fokozódását eredményezi majd. A nyíltan SCforH megközelítésben múködő sportegyesületek szervezeti keretként képesek hozzájárulni ahhoz, hogy a környezetre gyakorolt egészségfejlesztő hatás által szociokulturális háttérre tekintet nélkül egyenlő esélyeket biztosítsanak minden, a rekreációban és sportban részt venni kívánó személynek. Ezáltal biztosítható, hogy a hátrányos vagy halmozottan hátrányos helyzetű személyek (felnőttek, gyermekek és családok) is új típusú szocializációs közegben, formális és nem formális tanulási környezetben vegyenek részt olyan tevékenységekben, ahol nem feltétlenül a teljesítmény, hanem az élményközpontúság, a személyiség- és készségfejlesztés a rendező elv (grassroots sport szellemiség), és amelyek gyermekek esetében a koncentrációs és szocializációs készségek fejlesztésével kihathatnak a korai iskolaelhagyási mutatók javulására is.

'Kokko, S. 2010. Health Promoting Sports Club - Youth sports clubs' health promotion profiles, guidance, and associated coaching practice, in Finland. Studies in Sport, Physical Education and Health 144. Doctoral thesis. Jyväskylä: University of Jyväskylä. 


\section{A SCforH MEGKÖZELITTÉS?}

A „Sportegyesületek az egészségért” olyan szakértői szemléletmód, amely támogatja a sportegyesületeket, valamint az országos és regionális sportszervezeteket a sportágaikban rejlő egészségvédő potenciál felismerésében és a sportegyesületi körülmények közötti egészségjavító sporttevékenységek szervezésében.

Az SCforH-megközelítés célja, hogy a sportegyesületeket és országos sportszervezeteket arra ösztönözze, hogy több ráfordítással segítsék elő a saját sporttevékenységeik, mozgásformáik egészségvédő potenciáljának kihasználását. Ez a gyakorlatban mindenekelőtt az egyesületen belüli egészségjavító sporttevékenységek népszerüsítését jelenti. További egészségügyi előnyöket lehet elérni az egészségre nevelés biztosításával és az egészség sportegyesületen belüli népszerúsítésével, ami az egészségtámogató sportegyesületi (Health Promoting Sports (lub - HPSC) kezdeményezési központi célja. A sportegyesületek ugyanis kétféleképpen juthatnak előnyhöz: egyrészt azzal, hogy támogatják és növelik a sporton keresztüli egészségvédő testmozgást (SCforH-szemlélet), másrészt azzal, hogy a sportegyesületek helyszínt biztosítanak az általánosabb egészségmegőrzéshez („egészségtámogató sportegyesületek" [HPSC] szemlélet).

A jó egészségi állapot a sportegyesületi tagok és a társadalom egésze számára kívánatos cél, függetlenül attól, hogy a személy milyen okból sportol. Az SCforH-modell szorgalmazza, hogy a sportegyesületek vizsgálják felül saját tevékenységeiket és sportágaikat azok egészségügyi potenciáljának fényében, és ösztönözzék a nagyobb arányú részvételt az egészségjavító sporttevékenységekben.

1. ábra: A SCforH-szemlélet 7 vezérelv mentén javasolja az egészségorientált sportegyesület müködését. Az elvek alapján egy egészségorientált sportklub:

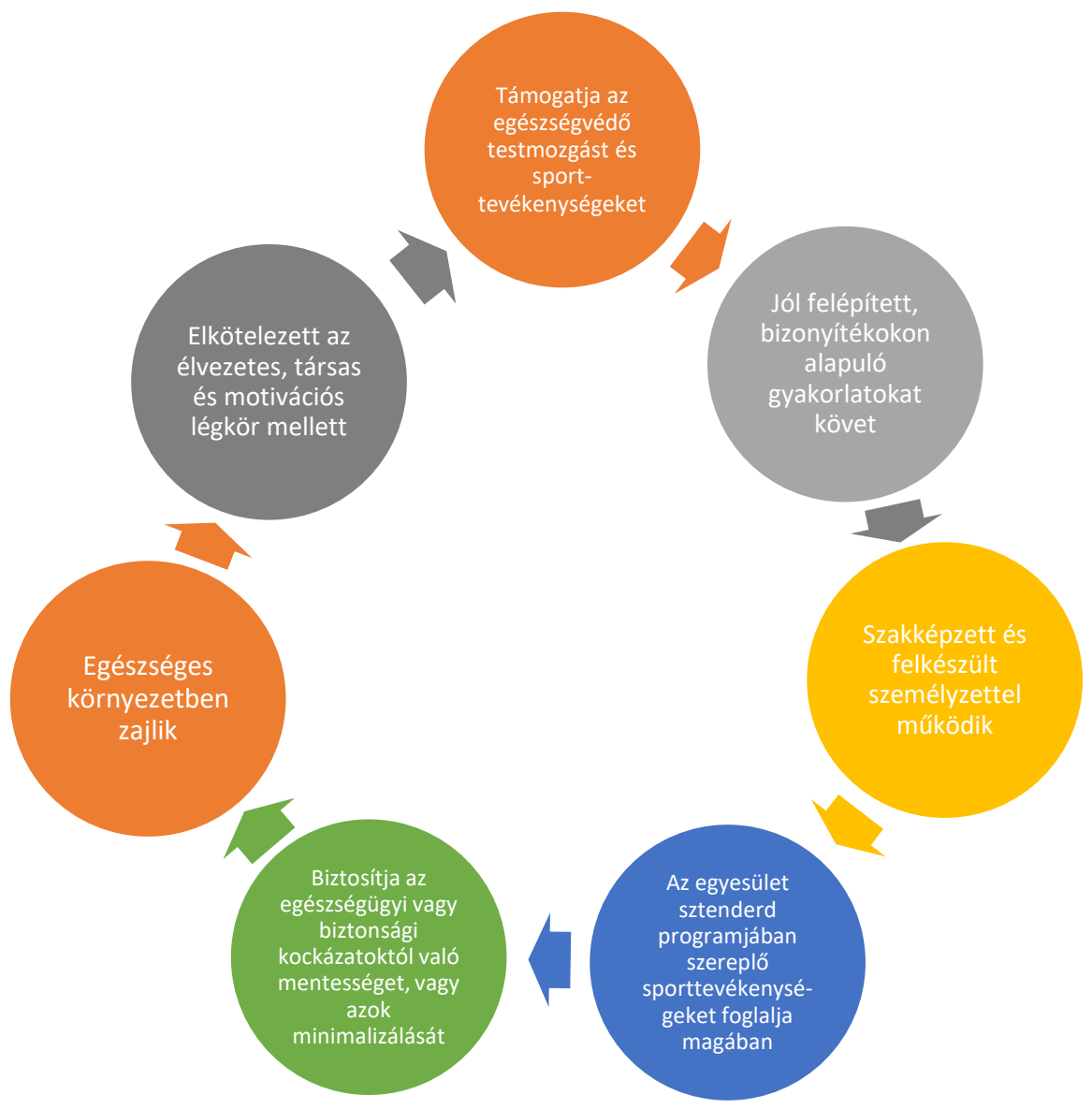

Forrás: https://www.scforh.info/content/uploads/2017/03/scfh2017_verkko.pdf 
A nemzetközileg kidolgozott modell és annak vezérelvei erős iránymutatásként szolgálnak a „Több, mint egy klub” projekt hazai megvalósítása során.

\section{AZ SCforH-SZEMLÉLET AZ ALÁBBI ELGONDOLÁSOKON ALAPUL:}

- Az SCforH-szemlélet arra szolgál, hogy minden sportegyesületben használják. Bármilyen típusú sportegyesületben be lehet vezetni, a kis, tisztán önkéntes jellegû egyesületektől egészen a fizetett szakemberekkel dolgozó, nagy egyesületekig.

- Az egyesületek között a sportcéljaik és programjaik terén is vannak különbségek. Az SCforH-szemlélet bármilyen sportegyesületben alkalmazható, az egyesület céljaitól és a kínálatában szereplő sportágaktól függetlenül.

- Az Egészségügyi Világszervezettel összhangban, az SCforH-megközelítés alapján az egészségnek definíció szerint három fő dimenziója van: testi, mentális és szociális. A sportegyesületekben indított SCforH-kezdeményezéseket lehet úgy módosítani, hogy a hangsúlyt az egészség fenti dimenziója közül valamelyikre vagy mindháromra helyezzék.

- Az SCforH-szemlélet a gyakorlatban egyfajta szemléletmódként alkalmazható, amely irányt mutat a sportegyesület és/vagy a tevékenységeinek múködtetéséhez vagy egy tervezett projekt vagy program lebonyolításához.

- Az SCforH-modellben arra kell törekedni, hogy az SCforH-szemlélet ne kívülálló kezdeményezés legyen, hanem végső soron beépüljön az egyesület napi szintű tevékenységeibe, például az edzésbe.

- Az SCforH-szemléletet úgy alakították ki, hogy a sportegyesületek tagjait és résztvevőit egyszerre szolgálja minden korcsoportban: gyermekeket, serdülőket, felnőtteket és időseket egyaránt.

Az SCforH nagyszabású nemzetközi kezdeményezés olyan támogatókkal, mint az Európai Bizottság, az Európai Hálózat az Egészségjavító Testmozgás Népszerúsítéséért - HEPA Europe, az Európai Nem
Kormányzati Sportszervezet (ENGSO), az Európai Vállalati Sportszövetség (EFCS), a Nemzetközi Sportés Kulturális Szövetség (ISCA) és a Nemzetközi Szabadidősport Szövetség (TAFISA). Az eddig támogatásban részesülő két SCforH-projektben 12 európai országból több mint 30 partner-, társult és támogató intézmény vett részt, köztük azonban nem volt magyar. Az SCforH-koncepcióra több mint 30 alkalommal hivatkoztak tudományos publikációkban és 140 alkalommal más típusú kiadványokban.

\section{MIÉRT ÉRDEMES BEVEZETNI AZ SCforH-SZEMLÉLETET?}

Európában közel egymillió sportegyesület és több mint 60 millió sportegyesületi tag van. A legújabb eredmények azt jelzik, hogy a sportegyesületek 37\%-a kínál egészségjavító fizikai aktivitási programokat, ugyanakkor 75\%-uk úgy érzi, hogy a sportágai alkalmasak az egészségjavító testmozgásra. Ez összességében azt mutatja, hogy az SCforHszemlélet európai sportegyesületekben való jövőbeni bevezetése nagyon komoly lehetőségeket rejt magában.

A sportegyesületek számára várhatóan számos előnnyel jár az SCforH-megközelítés alkalmazása. Először is, az SCforH-szemlélet utat mutat az egyesület fejlesztéséhez a tagok egészségének támogatásából származó előnyök kiaknázása révén. A tagok jobb egészségi állapota valószínúleg javítja a teljesítményüket és az elégedettségüket, emellett nagyobb részvételi arányhoz is vezet. Ez közvetlen javulást eredményez a sportegyesület alaptevékenységének sikerességében. Másodszor, a megvalósított SCforH-kezdeményezések új potenciális tagok érdeklődését is felkelthetik, és segithetik a toborzást. Harmadszor, az SCforH-szemlélet átvételével az egyesületek megkülönböztethetik magukat más sport- és fitneszszolgáltatóktól, és marketingelőnyökre tehetnek szert a versengő piacon. Negyedszer, az SCforH-szemlélet lehetőséget teremt a sport- és egészségügyi ágazatokban érintett gyakorló szakemberek, kutatók és politikai döntéshozók közötti partnerségek kialakítására. Ez viszont segítheti a sportegyesületek és országos 
szervezetek érdemi, fontos érdekeltként való térnyerését a népegészségügy területén.

Amellett, hogy a sportegyesületek és résztvevőik szempontjából pozitív következményekkel jár, az SCforH-szemléletből a helyi, regionális és országos sportszervezetek közvetlen előnyt is kovácsolhatnak. Az sCforH-szemlélet átvétele révén e szervezeteknek több lehetősége lesz arra, hogy finanszírozáshoz jussanak a sport- és közegészségügyi ágazatban, növeljék a közösségben betöltött szerepüket, és szélesebb közönséget érjenek el azáltal, hogy minden korcsoportban népszerűsítik a sportágaikat, mozgásformáikat.

\section{SCForH-SZEMLÉLET HAZAI ADAPTÁCIÓJÁNAK ÉS TOVÁBBFEJLESZTÉSÉNEK LEHETŐSÉGE|}

A Nemzeti Diák-, Hallgatói és Szabadidősport Szövetség (NDHSZ) és konzorciumi partnere, a Debreceni Egyetemi Atlétikai Club (DEAC) közös projektjében az SCforH-szemlélet jelenti a kiindulási alapot. A projekt megvalósítási folyamatát ugyanakkor a hazai és kifejezetten a helyi viszonyokhoz szükséges alakítani, ezért az eredeti SCforH-szemlélet és további nemzetközi példák megismerése mellett egyéni, innovatív megoldás kidolgozása szükséges. 